\author{
木 村 邦 夫 $^{1}$ 石 橋 修 ${ }^{1}$
}

\title{
Refinement of the Grained Low-Grade Amakusa Pottery Stone by Hydrothermal Treatment
}

by Kunio KIMURA ${ }^{1}$ and Osamu ISHIBASHI ${ }^{1}$

1. Kyushu National Industrial Research Institute, Shuku-machi, Tosu-shi 841

\begin{abstract}
A method of hydrothermal treatment has been tested to refine low-grade Amakusa pottery stones in both size ranges from 2.36 to 4.75 and from 4.75 to $9.5 \mathrm{~mm}$ in order to upgrade for pottery use. Hydrochloric acid, $0.14 \mathrm{~mol} / 1$, with addition of aluminum chloride is proved effective to alter albite into kaolin mineral under the hydrothermal condition at $200{ }^{\circ} \mathrm{C}$. This improves in the refractoriness of the treated samples as much as the same grade of the common high-grade Amakusa pottery stone. The treatment contributes to whiteness by decreasing $\mathrm{Fe}_{2} \mathrm{O}_{3}$ content of the products.
\end{abstract}

KEY WORDS : Amakusa Pottery Stone, Hydrothermal Treatment, Pottery Raw Material, Kaolin Mineral

1. 緒

天草陶石は有田・波佐見焼の主原料として用いられている。この 天草陶石の主要鉱物成分は, 石英, セリサイト, カオリン鉱物から なる。しかし, 各種の低品位陶石中には, 不純物として曹長石, 褐 鉄鉱, 菱鉄鉱, 方解石などが含まれている。最近, 高品位陶石が枯 渴化傾向にあるため, 低品位陶石を有効利用する必要に迫られてい る。現在, $15 \sim 20 \%$ 高濃度塩酸処理により, 褐鉄鉱, 菱鉄鉱; 方解石などが除去されている ${ }^{1)}$ が, 曹長石を含むものは, 耐火度 $(\mathrm{S} \mathrm{K})$ が低く, S K 26 以上という有田・波佐見焼等の磁器素地原 料としての一つの条件を満たすことができない。S K 18～20のあ のは, 低火度陶石として, 一部利用されているが, S K 17 以下のも のは, 全く利用されていないのが現状である。

長石を変質させる方法としては, 水熱反応による方法が古くより 行われている(2)-4) が, 一般に温度・圧力が高く, 工業的にその方法 を応用するには限界があった。しかしながら筆者らは先に, 上記の 未利用低火度陶石を $75 \mu \mathrm{m}$ 以下に粉砕した陶土中の曹長石が, 低 温・低圧（温度 : $180 \sim 200{ }^{\circ} \mathrm{C}$, 水蒸気圧: 約 $1 \sim 1.5 \mathrm{MPa}$ )下, 数日間の低濃度塩酸溶液中での水熱処理で分解すること, 条件によっ ては, カオリン鉱物が生成すること, さらに, 塩化アルミニウムを 添加すると, 処理時間が大幅に短縮され, 鉄含有量も半分以下にな り, 高級陶土としての利用が可能であることを明らかにした ${ }^{5)}$ 。

しかし, この方法によると, 被処理物の粒度が小さいため水熱処 理後の洗浄工程に長時間を要すること, また, 溶液/試料量が $10 \mathrm{ml}$ /g と多量の溶液を用いたため処理効率が著しく劣ること等, 工業 化を考えると問題点が多い。そこで, 今回, これらの問題点を解決 する目的で, 粒状試料を用いて水熱精製を試みたので, これらの結 果について報告する。

\footnotetext{
* 1994年 1 月 21 日受付 4 月 4 日受理 資源・素材学会平成 6 年度春季大会にて 一部発表

1. 正会員 工博 九州工業技術研究所ファイン素材部

キーワード : 天草陶石, 水熱処理, 陶磁器原料, カオリン鉱物
}

\section{2. 実}

\section{$2 \cdot 1$ 実験試料}

熊本県天草郡に産する数種の陶石脈 ${ }^{6)}$ の中から, 皿山脈の合通採 掘場, 海岸脈の門の迫採掘場および新山五坑採掘場より, 曹長石が 含まれている低品位の陶石を採取した。実験には, これらの 3 種類 の陶石を 10 mm以下に粗砕した後, $2.36,4.75,9.5 \mathrm{~mm}$ ぶるい分 け, 得られた $2.36 \sim 4.75 \mathrm{~mm}, 4.75 \sim 9.5 \mathrm{~mm}$ の各々 2 区分, 合 計 6 試料を用いた。なお， 3 種類の陶石すべて, 各 2 区分の合計量 は粗碎試料全量の $50 \mathrm{wt} \%$ 以上含まれていた。以下, 本論文では重 量パーセントを用い, 単に\%と記載する。また，合通，門の迫およ び新山五坑の各採掘場より採取した試料を，それぞれU G, U K お よびK S試料， $4.75 \sim 9.5 \mathrm{~mm}$ の区分を $\mathrm{L} ， \quad 2.36 \sim 4.75 \mathrm{~mm}$ の区分 を $\mathrm{S}$ と略称する。

\section{$2 \cdot 2$ 水熱処理}

水熱処理条件をTable 1 に示す。水熱処理には, $70 \mathrm{ml}$ テフロン 容器およびステンレススチール製ジャケットからなる密閉容器を用 い, 試料量は 1 実験に $40 \mathrm{~g}$ を用いた。この量は, 容器の約 8 分目ま で充てんされる量である。

塩酸の添加は，脱鉄および脱カルシウムを目的としたものである。 溶液/試料量は, 前報告 ${ }^{5)}$ では $10 \mathrm{ml} / \mathrm{g}$ としたが, これは, 工業化を 考えると溶液が多く, 処理効率が著しく劣ると思われる。そこで, 今回の粒状試料では $1 \mathrm{ml} / \mathrm{g}$ とした。この量は, 粒状試料が溶液に

Table 1 Experimental conditions for hydrothermal treatment.

\begin{tabular}{|c|c|}
\hline Factor & Ranges \\
\hline $\begin{array}{l}\mathrm{HCl} \text { content of solution }(\mathrm{mol} / \mathrm{\ell}) \\
\text { Ratio of solution/sample (ml/g) }\end{array}$ & $\begin{array}{lll}0 . & 0.14, & 0.28 \\
1 & & \end{array}$ \\
\hline Ratio of $\mathrm{AlCl}_{3} /$ sample & $\begin{array}{l}0.10 \text { (for all sample) } \\
0.26 \text { (for sample UG) } \\
0.16 \text { (for sample UK) }\end{array}$ \\
\hline $\begin{array}{l}\text { Temperature } \\
\text { Time }\end{array}$ & $\begin{array}{l}200 \\
120\end{array}$ \\
\hline
\end{tabular}


Table 2 Chemical compositions of raw samples and high grade pottery stone.

\begin{tabular}{l|rlllllllll:}
\hline Sample & $\mathrm{SiO}_{2}$ & $\mathrm{TiO}_{2}$ & $\mathrm{Al}_{2} \mathrm{O}_{3}$ & $\mathrm{Fe}_{2} \mathrm{O}_{3}$ & $\mathrm{CaO}$ & $\mathrm{MgO}$ & $\mathrm{Na}_{2} \mathrm{O}$ & $\mathrm{K}_{2} \mathrm{O}$ & Ig. loss & Total \\
\hline UG & 75.46 & 0.02 & 14.83 & 0.85 & 0.09 & 0.14 & 3.02 & 3.13 & 1.58 & 99.12 \\
UK & 76.46 & 0.05 & 14.83 & 1.10 & 0.03 & 0.15 & 1.85 & 2.35 & 2.23 & 99.05 \\
KS & 74.02 & 0.02 & 14.45 & 0.83 & 2.19 & 0.16 & 1.12 & 3.33 & 4.37 & 100.49 \\
\hline high grade & 79.80 & 0.01 & 13.73 & 0.29 & 0.04 & 0.09 & 0.08 & 3.72 & 2.47 & 100.23 \\
\hline
\end{tabular}

Table 3 Refractoriness and whiteness of fired raw samples.

\begin{tabular}{l|c|c}
\hline Sample & $\begin{array}{c}\text { refractoriness } \\
(\text { SK })\end{array}$ & $\begin{array}{c}\text { whiteness } \\
(-)\end{array}$ \\
\hline UG & 14 & 58.7 \\
UK & 18 & 62.5 \\
KS & 15 & 59.7 \\
\hline high grade & $26+$ & 85.0 \\
\hline
\end{tabular}

すべて浸漬する限界量に近い值である。また, 試料量に対する溶液 量を少なくしたことにより, 脱鉄および脱カルシウムが困難になる こと屯予想されたので, 塩酸濃度を $0,0.14,0.28 \mathrm{~mol} / 1$ (\%濃度 では, $0,0.5,1 \%$ ) と変化させた。また, 反応は遅いが, 塩酸だ けでも曹長石 $\left(\mathrm{Na}_{2} \mathrm{O} \cdot \mathrm{Al}_{2} \mathrm{O}_{3} \cdot 6 \mathrm{SiO}_{2}\right)$ の分解とカオリン鉱物 $\left(\mathrm{Al}_{2} \mathrm{O}_{3} \cdot 2 \mathrm{SiO}_{2} \cdot 2 \mathrm{H}_{2} \mathrm{O}\right)$ の生成が起こる $\left.{ }^{5)} 7\right)$ 。この場合の反応は, (1)式が考えられる7)。

$$
\begin{aligned}
\mathrm{Na}_{2} \mathrm{O} \cdot \mathrm{Al}_{2} \mathrm{O}_{3} \cdot 6 \mathrm{SiO}_{2}+2 \mathrm{HCl}+\mathrm{H}_{2} \mathrm{O} \rightarrow \\
\mathrm{Al}_{2} \mathrm{O}_{3} \cdot 2 \mathrm{SiO}_{2} \cdot 2 \mathrm{H}_{2} \mathrm{O}+2 \mathrm{NaCl}+4 \mathrm{SiO}_{2}
\end{aligned}
$$

塩化アルミニウムの添加は, (2)式のように, 曹長石がカオリン鉱 物に変化するときに不足する $\mathrm{Al}_{2} \mathrm{O}_{3}$ を補い, 反応を促進する ${ }^{5) 7)}$ 。

$$
\mathrm{Na}_{2} \mathrm{O} \cdot \mathrm{Al}_{2} \mathrm{O}_{3} \cdot 6 \mathrm{SiO}_{2}+4 \mathrm{AlCl}_{3}+11 \mathrm{H}_{2} \mathrm{O} \rightarrow
$$$$
3\left(\mathrm{Al}_{2} \mathrm{O}_{3} \cdot 2 \mathrm{SiO}_{2} \cdot 2 \mathrm{H}_{2} \mathrm{O}\right)+2 \mathrm{NaCl}+10 \mathrm{HCl}
$$

そこで, $\mathrm{AlCl}_{3} /$ 試料量は, 試料に含まれている $\mathrm{Na}_{2} \mathrm{O}$ がすべて曹 長石に含まれている $\mathrm{Na}_{2} \mathrm{O}$ であるとの仮定の基に, 上記(2)式により 算出される値とした。また, 比較のため, 前報告 ${ }^{3)}$ で最適と判断し た $0.1 \mathrm{~g} / \mathrm{g}$ の実験も行った。なお, K S 試料の上記(2)式による算出 值は $0.1 \mathrm{~g} / \mathrm{g}$ で, 前報告 ${ }^{3)}$ の最適值と一致した。実験には塩化アル ミニウムの 6 水塩 $\left(\mathrm{AlCl}_{3} \cdot 6 \mathrm{H}_{2} \mathrm{O}\right)$ を用いた。

なお, 温度, 圧力, 処理時間は, 前報告 ${ }^{5)}$ で最適と判断した 200

${ }^{\circ} \mathrm{C}$, 約 $1.5 \mathrm{MPa}$ (200 ${ }^{\circ} \mathrm{C}$ における水蒸気圧), $120 \mathrm{~h}$ とした。

水熱処理後の試料は, 濾過, 水洗, 乾燥し, 次に述べる方法によ り, 各種分析を行った。

\section{$2 \cdot 3$ 処理前後試料の物性測定}

水熱処理後の試料は, 処理前の粒度より小さくなっていた。そこ で, ロータップシェーカーを用いて粒度分布を測定した。使用した ふるいは, 75, 150, 300, $600 \mu \mathrm{m}, 1.18,2.36,4.75 \mathrm{~mm}$ の標準ふ るいである。

鉱物組成の変化を検討するため, ステップスキャン法により粉末 X線回折強度を測定するとともに, セリサイト, カオリン鉱物, 石 英，長石の積分強度を测定した。なお，本実験試料に含まれている 長石は, そのほとんどが曹長石であるが, 曹長石だけの積分強度の 測定は困難である。そこで,ここでは長石の積分強度を求めた。装 置はフィリップス製 APD- 15 型を用いた。条件は, 電圧 : $30 \mathrm{kV}$, 電流 : $20 \mathrm{~mA}$, ステップ幅 : $0.05^{\circ}$, 测定時間 : 2 秒/ステップと した。積分強度の測定角度 $(2 \theta)$ は, セリサイト $: 8.30 \sim 9.50^{\circ}$, カオリン鉱物 : $12.00 \sim 13.30^{\circ}$, 石英 : $26.20 \sim 27.30^{\circ}$, 長石 : $27.30 \sim 28.30^{\circ}$ とした。

天然原料の粉末 X線回折における粘土鉱物の積分強度は, その含 有割合にほぼ比例するが, 水熱反応により初期に生成するカオリン 鉱物は微粒であるため, 必ずしも積分強度值に比例しない ${ }^{5)}$ 。一方, 熱重量の測定における $400 \sim 1,000^{\circ} \mathrm{C}$ 間の加熱減量値は, 粘土釷物の 量にほぼ比例し ${ }^{5)}$, 炭酸塩鉱物が含まれていない場合, その量は粘 土鉱物の構造水の量に相当する。そこで, $400 \sim 1,000^{\circ} \mathrm{C}$ 間の加熱減 量値を構造水量とし, 粘土鉱物の増減の目安とした。装置は真空理 工製 TGD- 5000 型を用いた。条件は, 試料量 : 約 $150 \mathrm{mg}$, 昇温 速度 : $20^{\circ} \mathrm{C} / \mathrm{min}$ とした。

耐火度は, 筆者らが開発した熱膨張曲線の測定を基にする耐火度 の推定方法 ${ }^{8)}$ による值とした。

化学組成は, フィリップス製 $\mathrm{PW}-1400$ 型蛍光 X 線分析装置に
より求めた。なお，検量線は，34:個の天草陶石試料の湿式法による 化学分析値と, 同試料の乾式プレス法による蛍光X線分析値を基に 作成した。

白色度は, 熱膨張曲線の測定による耐火度の推定で得られる直径 $10 \mathrm{~mm}$ 弱の平板状ペレットについて, 色差計で測定した Lab 值か ら算出 ${ }^{9)}$ した。なお, 熱膨張曲線の測定における最高温度は, 試料 の耐火度により変化させており, 大略, S K 14 で $1,310{ }^{\circ} \mathrm{C}$, S K 18

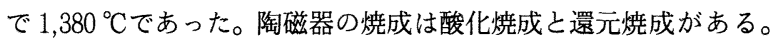
熱膨張曲線の測定は, 空気中で行っているため, この白色度は, 酸 化佬成で得られる陶磁器の白色度を表していることになる。

\section{3，実験結果と考察}

\section{3 - 1 原料の性状}

実験に用いた 3 種類の陶石および最高級の陶石である特等石の化 学組成を Table 2 に, 耐火度抢よび焼成物の白色度を Table 3 に示 す。なお，特等石は，皿山脈の伝兵衛木場採掘場から採取したもの である。一般に天草陶石は, 低品位でも Table 2 に示すように, $\mathrm{TiO}_{2}$ の含有量が極めて少ないのが特徴である。また, 実験に用い た試料は, 特等石に比へ, $\mathrm{Fe}_{2} \mathrm{O}_{3}, \mathrm{CaO}, \mathrm{Na}_{2} \mathrm{O}$ が多く含まれてい る。曹長石の含有割合は, Table 2 の $\mathrm{Na}_{2} \mathrm{O}$ がすべて曹長石中に存 在すると仮定すると, U G 試料で約 $26 \%, \mathrm{UK}$ 試料で約 $16 \%, \mathrm{~K} \mathrm{~S}$ 試料で約 $9 \%$, 特等石で $1 \%$ 以下となる。

現在出荷されている天草陶石の品位は, 耐火度が S K 26 以上で, $\mathrm{Fe}_{2} \mathrm{O}_{3}$ 含有割合が $1 \%$ 以下゙ある。等級は, $\mathrm{Fe}_{2} \mathrm{O}_{3}$ 含有割合により, $0.4 \%$ 以下が特等石, $0.4 \sim 0.5 \%$ が 1 等石, $0.5 \sim 0.7 \%$ が 2 等石, $0.7 \sim 0.9 \%$ が 3 等石, $0.9 \sim 1.0 \%$ が 4 等石と定められている ${ }^{1)}$ 。 一方, 通常の陶磁器用粘土,例えば陶磁器原料用木節粘土の $\mathrm{Fe}_{2} \mathrm{O}_{3}$ 含有割合は, $0.33 \sim 2.65 \%, \mathrm{Na}_{2} \mathrm{O}$ 含有割合は $0.07 \sim 1.05 \%$, 耐 火度はS K26〜 35+である ${ }^{10)}$ 。これらの值と比較すると，供試料 の $\mathrm{Fe}_{2} \mathrm{O}_{3}$ 含有割合は多く, $\mathrm{Na}_{2} \mathrm{O}$ の含有割合も多い。このため, Table 3 に示した耐灭度が低く, 白色度も小さな值になっていると 推察される。このような物性では, 3 試料とも, 陶磁器原料として

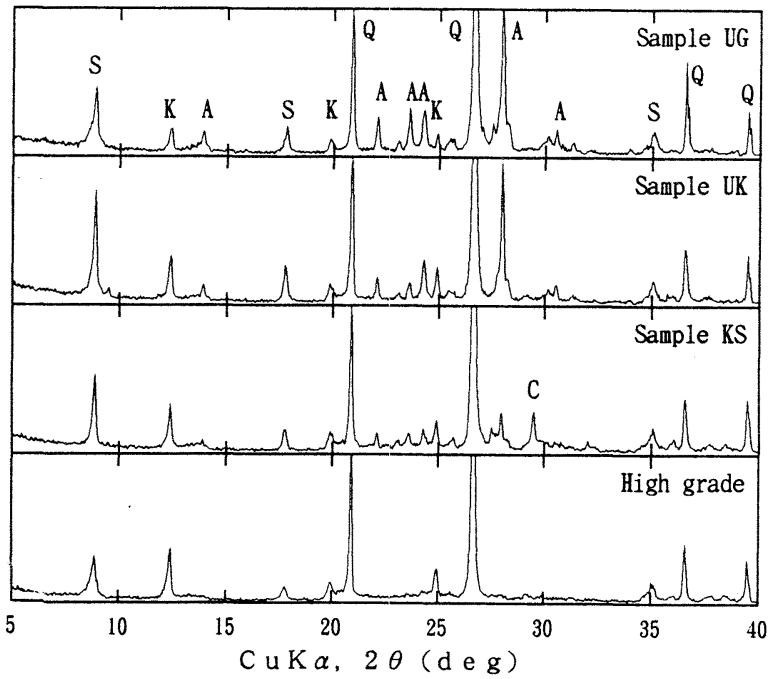

Fig. 1 X-ray powder diffraction pattern of pottery stone-samples from Amakusa.

S:sericite, K:kaolin mineral, Q:quartz, A:albite, C:calcite 
Table 4 X-ray integrated intensities of sericite, kaolin mineral, quartz and feldspar, and stractural water contents of raw samples.

\begin{tabular}{l|c|c|c|c|c}
\hline \multirow{2}{*}{ Sample } & \multicolumn{3}{|c|}{ Relative diffraction intensity } & Stractural water \\
\cline { 2 - 5 } & sericite & kaolin & quartz & feldspar & (wt\%) \\
\hline UG & 28 & 8 & 184 & 57 & 1.42 \\
UK & 37 & 15 & 211 & 35 & 2.07 \\
KS & 24 & 14 & 199 & 11 & - \\
\hline High grade & 18 & 17 & 161 & - & 1.94 \\
\hline
\end{tabular}

は使用できない。

各試料の粉末 X線回折図を Fig. 1 に示す。Fig. 1 によると, 各 試料とも，主鉱物は石英，セリサイト，カオリン鉱物であるが，特 等石に比べ, UGおよびU K試料には曹長石が， K S 試料には方解 石が多く含まれている。

上記の粉末 X線回折測定で得られたセリサイト，カオリン鉱物， 石英, 長石の積分強度値を Table 4 に示す。Table 4 には, セリサ イト，カオリン鉱物等の粘土鉱物の含有量に比例する構造水量も示 した。なお, $\mathrm{K} \mathrm{S}$ 試料の $400 \sim 1,000^{\circ} \mathrm{C}$ 間の加熱減量值には，方解 石中の炭酸ガスが含まれるため, この試料の構造水量は記載してい ない。

Table 4 によると, 3 試料とも, 特等石に比べ, セリサイトと曹 長石が多く含まれ，カオリン鉱物は少ない。

\section{$3 \cdot 2$ 粒度分布}

これまでに，今回と同じ粒状試料を用いて，脱鉄，脱カルシゥム の処理時間を短縮する目的で, $150{ }^{\circ} \mathrm{C}$, 約 $0.5 \mathrm{MPa}\left(150{ }^{\circ} \mathrm{C}\right.$ での水

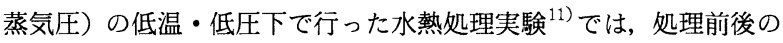
粒度はほとんど変化しなかったが，今回は，大きく変化した。

一例として，3 種類の陶石の中では最も粒度変化の大きかった $\mathrm{UG}$ - L試料と変化の少なかった $\mathrm{K} \mathrm{S}$ - L 試料の水熱処理後の粒度 分布を Fig. 2 に示す。UK-L試料は, 両試料の中間的な粒度分 布であった。
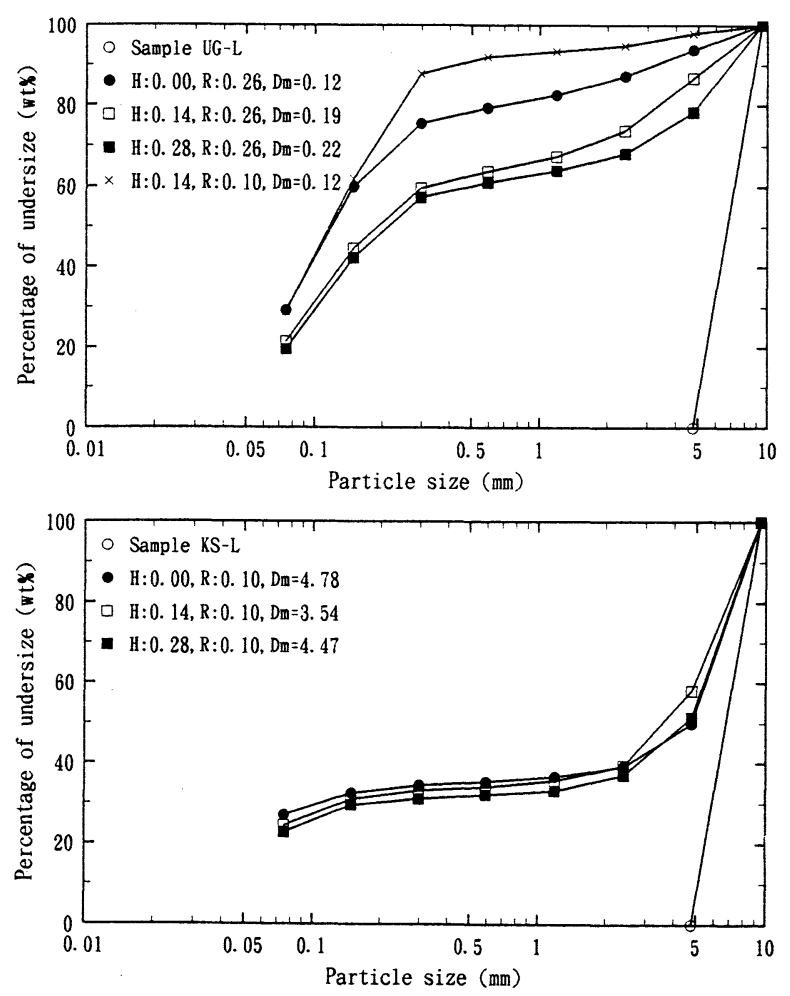

Fig. 2 Particle size distribution of samples after hydrothermal treatment of the sample UG-L and KS-L.

$\mathrm{H}: \mathrm{HCl}$ content(mol/1), R:ratio of $\mathrm{AlCl}_{3} /$ sample $(\mathrm{g} / \mathrm{g})$, Dm:median diameter $(\mathrm{mm})$
Fig. 2 によると, U G - L試料では, 水熱条件により著しく差が 認められ， $50 \%$ 平均粒径は， $0.12 \sim 0.22 \mathrm{~mm}$ とすべて処理前の 1/10以下となっている。しかし, K S - L試料では, 水熱条件によ る差はほとんど認められない。また，50\%平均粒径は，3.54〜 4.78 $\mathrm{mm}$ とすべて処理前の $1 / 10$ 以上である。後述の鉱物組成, 化学組成 等の変化は, U G試料が最も大きい。これらの結果は, 鉱物組成, 化学組成等の変化が大きい試料ほど, 細粒化する傾向があることを 示している。前述の低温, 低圧下での鉄, カルシウムの溶脱を目的

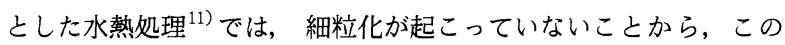
細粒化は, 上記 2 ・2 で示した(2)式の反応における曹長石の分解 とカオリン鉱物の生成に起因していると推察される。

$\mathrm{UG}-\mathrm{S}, \mathrm{UK}-\mathrm{S}, \mathrm{K} \mathrm{S}-\mathrm{S}$ 試料では, 陶石の種類による傾向 は上記の粒度範囲の試料とほぼ同じであったが, 細粒化は若干少な かった。

この細粒化は, 水熱処理後の工業的な水洗工程に若干のマイナス 要因を与えることが考えられる。しかし，平均粒径 0.12〜4.78 $\mathrm{mm}$ に細粒化した本実験試料の水熱処理後の水洗工程に要する時間 は， $3 \mu \mathrm{m}$ 以下の粒子が約 $60 \%$ む含まれている陶土 ${ }^{5)}$ を精製する 場合に比べ，大幅に短縮できると思われる。

\section{$3 \cdot 3$ 回収率}

水熱処理前後の乾燥重量百分率として算出される回収率は, 脱鉄, 脱カルシゥムを目的とした低温，低圧下での水熱処理実験の結果で は, 鉄およびカルシウムの溶脱のため, $92 〜 97 \%$ であった ${ }^{11)}$ が, 今回の実験では, 試料の粒度範囲に関係なく, U G およびU K 試料 でほぼ $100 \%$ ，K S試料で $97 \%$ \%でった。（2)式によると，1９の 曹長石から $1.48 \mathrm{~g}$ のカオリン鉱物が生成することになり, 重量が増 加するはずである。U GおよびU K 試料では, 上記の増加と鉄, 力 ルシウムの溶脱による減少および下記 3 ・4 に示すセリサイトの若 干の減少等とが相殺されたものと考えられる。一方, K S試料は, Fig. 1 に示したように, 曹長石の含有量む他試料に比べ少なく, ま た，方解石を他試料に比べ多く含んでいる。カオリン鉱物が生成し 増加する量に比べ, 鉄とカルシウムの溶脱量が多かったため, 回収 率が若干少なくなったと考えられる。

\section{$3 \cdot 4$ 鉱物組成の変化}

一例として，粒度分布を示した U G - L 試料の水熱処理後の粉末 X線回折図をFig. 3 に, K S - L 試料の水熱処理後の粉末 X線回折

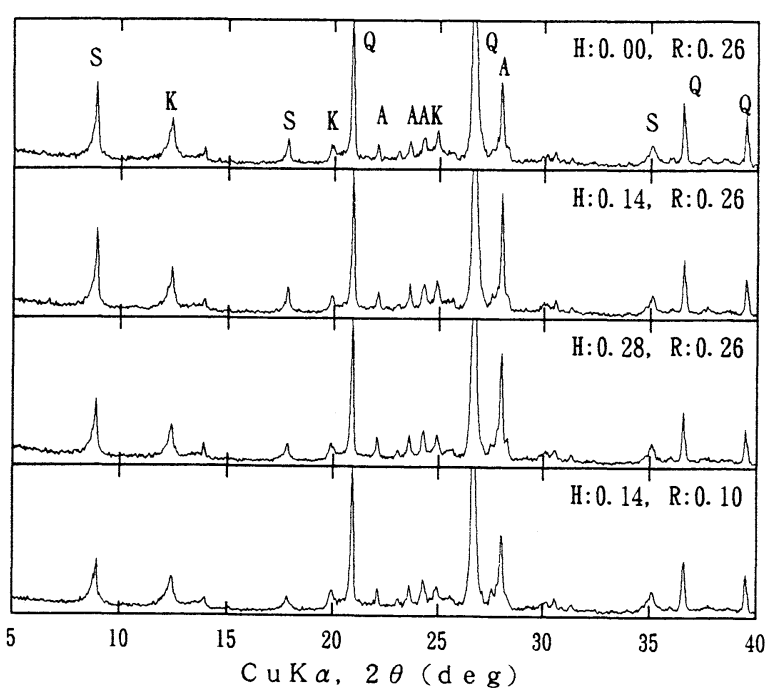

Fig. 3 X-ray powder diffraction pattern of samples after hydrothermal treatment of the sample UG-L. $\mathrm{H}: \mathrm{HCl}$ content $(\mathrm{mol} / \mathrm{l})$, R:ratio of $\mathrm{AlCl}_{3} /$ sample $(\mathrm{g} / \mathrm{g})$. $\mathrm{S}:$ sericite, K:kaolin mineral, Q:quartz, A:albite 


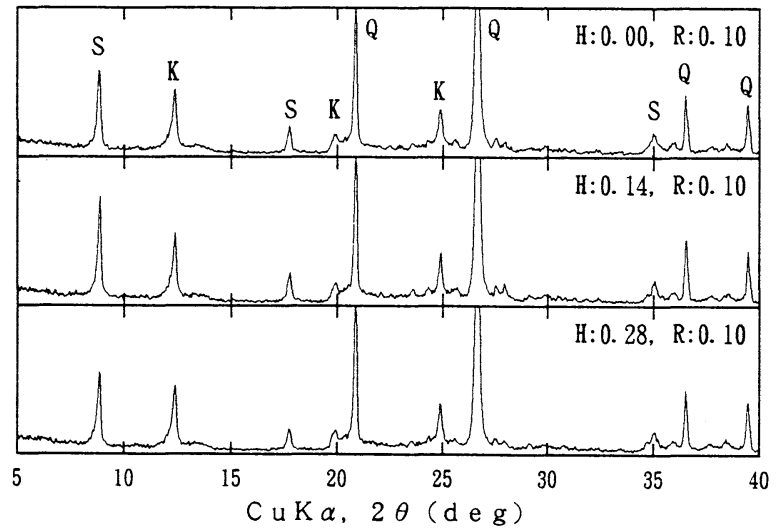

Fig. 4 X-ray powder diffraction pattern of samples after hydrothermal treatment of the sample KS-L. $\mathrm{H}: \mathrm{HCl}$ content (mol/l), R:ratio of $\mathrm{AlCl}_{3} /$ sample $(\mathrm{g} / \mathrm{g})$. S:sericite, K:kaolin mineral, Q:quartz, A:albite

図をFig. 4 に示す。Fig. 3 によると, 曹長石の分解は, 塩酸濃度 と $\mathrm{AlCl}_{3} /$ 試料量が前報告 $^{5}$ で最適と判断された $0.14 \mathrm{~mol} / 1(0.5$ \%) と $0.1 \mathrm{~g} / \mathrm{g}$ の条件, あるいは塩酸を添加せずに塩化アルミニウ ムだけを理論量添加する条件で進んでいる。一方, Fig. 4 によると, Fig. 1 で示したK S 試料で認められた曹長石と方解石のピークはほ とんど認められない。この実験条件においては, 塩酸濃度と $\mathrm{AlCl}_{3}$ /試料量による差はほとんどない。

これらの試料も含め, 全試料, 全条件による実験後測定したセリ サイト, カオリン鉱物, 石英, 長石の積分強度值を Table 5 に示す。 Table 5 には, セリサイト, カオリン鉱物等の粘土鉱物の含有量に 比例する構造水量および曹長石の分解の指針となる $\mathrm{Na}_{2} \mathrm{O}$ 含有率 あ示した。セリサイトの積分強度は, Table 4 に示した原料に比べ, 若干減少する傾向か認められる。しかし, 上記 3 ・1 で示したよう に, 低品位陶石には, 高級陶石に比べセリサイトが多く含まれる傾 向がある。このことから, 水熱処理によるセリサイトの若干の減少 は, 利用面ではほとんど影響しないと思われる。UGおよびU K 試 料では,盐酸濃度と $\mathrm{AlCl}_{3} /$ 試料量が上記の $0.14 \mathrm{~mol} / 1$ と $0.1 \mathrm{~g} / \mathrm{g}$ の条件, あるいは塩酸を添加せずに塩化アルミニウムだけを理論量 添加する条件で, 長石の分解が進み, また, 粘土鉱物の含有量に比
例する構造水む増加する傾向を示している。

UGおよびUK K試料は, K S 試料に比べ, 曹長石の含有量が多く, 塩化アルミニウムの必要添加理論量は多くなる。塩化アルミニウム だけの添加でも $\mathrm{pH}$ は低くなり, さらに $0.14 \mathrm{~mol} / 1$ 以上の高濃度 塩酸を添加すると, $\mathrm{pH}$ はさらに低くなり, 曹長石の分解とカオリ ン鉣物の生成を阻害する7)。Table 5 に示した $\mathrm{Na}_{2} \mathrm{O}$ 含有率からも, 曹長石の分解が阻害されているここがうかがえる。一方, 塩化アル ミニゥムの添加は極力少ない方が工業的に有利である。これらのこ とから, 最適塩酸濃度は $0.14 \mathrm{~mol} / 1$, 最適塩化アルミニウム添加 量は $0.1 \mathrm{~g} / \mathrm{g}$ と考えられる。

一方, 粒度範囲の違いによる積分強度および構造水量の差は, わ ずかに認められるが，大きな差はない。これは, 天草陶石が熱水変 成により生成したため多孔質であることに起因していると考えられ る。すなわち, 多孔質であるため溶液が粒子中心まで到達している ことを示していると考えられる。この結果は, $9.5 \mathrm{~mm}$ より大き 粒子を用いても, 水熱精製が可能であることを示唆しているが，大 きくなると精製後の水洗が困難になるため, 工業的には限界がある と思われる。

\section{$3 \cdot 5$ 耐火度および白色度}

上記の最適と判断した条件で得られた処理物の耐火度および焼成 物の白色度をTable 6 に示す。前項と同様に, 禚度範囲の違いによ る差はほとんど認められない。耐火度は, Table 3 に示した原料の S K14 〜 S K18 がS K20 〜 S K26+に上昇している。これは, 水 熱処理による曹長石のカオリン鉱物化, 脱炭酸塩鉱物, 脱鉄等に起 因していると考えられる。

白色度は, 原料で 60 前後が処理試料では 80 以上となり, 精製効 果が現れている。これは, 水熱処理による脱鉄に起因していると考 えられる。

\section{$3 \cdot 6$ 化学組成の変化}

上記 $3 ・ 4$ で最適と判断した条件で得られた処理物の化学組成を Table 7 に示す。前項と同様に, 粒度範囲の違いによる差はほとん ど認められない。陶磁器原料としては, $\mathrm{Fe}_{2} \mathrm{O}_{3}, \mathrm{CaO}, \mathrm{Na}_{2} \mathrm{O}$ の含 有量は少ない方がよい。Table 2 に示した原料の化学組成と比較す ると, $\mathrm{Fe}_{2} \mathrm{O}_{3}$ 含有量は, 原料の $0.83 \sim 1.10 \%$ が大幅に減少し, 0.3 \%前後と特等石と同等の值になっている。また, $\mathrm{CaO}$ 含有量は,

Table 5 X-ray integrated intensities of sericite, kaolin mineral, quartz and feldspar, and stractural water and $\mathrm{Na}_{2} \mathrm{O}$ contents of samples after hydrothermal treatment.

\begin{tabular}{|c|c|c|c|c|c|c|c|c|}
\hline \multirow{2}{*}{ Sample } & \multicolumn{2}{|c|}{ Hydrothermal condition } & \multicolumn{4}{|c|}{ Relative diffraction intensity } & \multirow{2}{*}{$\begin{array}{l}\text { S tractural water } \\
(w \mathrm{t} \%)\end{array}$} & \multirow{2}{*}{$\begin{array}{r}\mathrm{Na}_{2} \mathrm{O} \\
(\text { wt\% })\end{array}$} \\
\hline & $\mathrm{HCl}(\mathrm{mol} / \ell)$ & $\mathrm{AlCl}_{3}(\mathrm{~g} / \mathrm{g})$ & sericite & kaolin & quartz & feldspar & & \\
\hline \multirow{4}{*}{ UG-L } & 0 & 0.26 & 26 & 18 & 183 & 25 & 2.76 & 1.55 \\
\hline & 0.14 & 0.26 & 29 & 18 & 173 & 34 & 2.52 & 1.89 \\
\hline & 0.28 & 0.26 & 23 & 15 & 176 & 33 & 2.36 & 2.02 \\
\hline & 0.14 & 0.10 & 21 & 16 & 168 & 28 & 2. 79 & 1.08 \\
\hline \multirow{4}{*}{ UG-S } & 0 & 0.26 & 20 & 20 & 178 & 23 & 2.97 & 1.53 \\
\hline & 0.14 & 0.26 & 23 & 12 & 149 & 30 & 2. 36 & 1.87 \\
\hline & 0.28 & 0.26 & 22 & 14 & 160 & 29 & 2.43 & 1.89 \\
\hline & 0.14 & 0.10 & 17 & 13 & 166 & 26 & 2.89 & 0.98 \\
\hline \multirow{4}{*}{ UK-L } & 0 & 0.16 & 27 & 29 & 207 & 11 & 3.35 & 0.69 \\
\hline & 0.14 & 0.16 & 34 & 33 & 225 & 9 & 3.21 & 0.62 \\
\hline & 0.28 & 0.16 & 28 & 25 & 216 & 8 & 3.02 & D. 59 \\
\hline & 0.14 & 0.10 & 25 & 27 & 214 & 8 & 3. 26 & D. 49 \\
\hline \multirow{4}{*}{ UK-S } & 0 & 0.16 & 29 & 22 & 193 & 16 & 3.02 & 0.79 \\
\hline & 0.14 & 0.16 & 32 & 20 & 209 & 15 & 2.92 & 0. 75 \\
\hline & 0.28 & 0.16 & 29 & 23 & 219 & 18 & 2.75 & 0.87 \\
\hline & 0.14 & 0.10 & 24 & 18 & 216 & 12 & 3.16 & 0.50 \\
\hline \multirow{3}{*}{ KS-L } & 0 & 0.10 & 28 & 23 & 207 & 1 & 3.71 & 0.27 \\
\hline & 0.14 & 0.10 & 31 & 26 & 201 & 4 & 3. 45 & 0.42 \\
\hline & 0.28 & 0.10 & 25 & 26 & 204 & 1 & 3.61 & 0.26 \\
\hline \multirow{3}{*}{ KS-S } & 0 & 0.10 & 28 & 24 & 215 & 4 & 3.38 & 0.40 \\
\hline & 0.14 & 0.10 & 25 & 20 & 205 & 3 & 3.53 & 0.40 \\
\hline & 0.28 & 0.10 & 27 & 23 & 213 & 3 & 3.47 & 0.36 \\
\hline
\end{tabular}


Table 6 Refractoriness and whiteness of fired samples after hydrothermal treatment.

\begin{tabular}{l|c|c}
\hline Sample & $\begin{array}{c}\text { ref ractoriness } \\
\text { (SK) }\end{array}$ & $\begin{array}{c}\text { whi teness } \\
(-)\end{array}$ \\
\hline UG-L & 20 & 81.0 \\
UG-S & 20 & 81.3 \\
\hline UK-L & $26-$ & 82.6 \\
UK-S & $26-$ & 82.4 \\
\hline KS-L & 26 & 84.0 \\
KS-S & $26+$ & 84.8 \\
\hline
\end{tabular}

方解石の含有量が多かった K S 試料で $0.05 \%$ 以下, 他試料で $0.01 \%$ 以下となっている。 $\mathrm{Na}_{2} \mathrm{O}$ 含有量は, 曹長石の含有量が多かっ たU G試料で $1 \%$ 前後, 他試料で $0.4 \sim 0.5 \%$ となっいる。Table 2 および Table 7 中の $\mathrm{Na}_{2} \mathrm{O}$ がすべて曹長石中に存在すると仮定す ると, 曹長石の含有割合は, U G 試料で処理前の約 $26 \%$ が約 $8 \%$ に, 他試料で処理前の 16 ～9\%が約 4 \%に減少したことになる。

\section{4. 結}

熊本県天草郡に産する天草陶石の皿山脈の合通採掘場, 海岸脈の 門の迫採掘場および新山五坑採掘場より, 曹長石が含まれている低 品位の陶石を採取, 粗砕, ふるい分けして得た $2.36 \sim 4.75 \mathrm{~mm}$, $4.75 \sim 9.5 \mathrm{~mm}$ の試料を用い, 工業的に精製処理が可能と考えられ る条件下で水熱処理し,下記の結果を得た。

1）最も効果的であった条件は, 試料量の $1 / 10$ の重量の塩化ア ルミニウムを添加し, $0.14 \mathrm{~mol} / 1$ の塩酸溶液を試料量と同重量加え, 容器を密閉し, $200{ }^{\circ} \mathrm{C}$ (約 $1.5 \mathrm{MPa}$ の水蒸気圧) で $120 \mathrm{~h}$ 処理する 条件であった。

2） $\mathrm{Na}_{2} \mathrm{O}$ がすべて曹長石中に存在すると仮定した曹長石の含有 割合は, 皿山脈の合通採掘場の低品位試料で処理前の約 $26 \%$ が約 8 \%に, 他試料で処理前の $16 \sim 9 \%$ が約 $4 \%$ に減少した。

3）耐火度は原料のS K 14〜S K 18が水熱好理による曹長石の力 オリン鉱物化, 脱炭酸塩鉱物および脱鉄等により, S K $20 \sim \mathrm{S} \mathrm{K}$ $26+$ に上昇した。

4）処理物の $\mathrm{Fe}_{2} \mathrm{O}_{3}$ 含有量は, 上記最適条件の場合, $0.3 \%$ 前後
Table 7 Chemical compositions of samples after hydrothermal treatment.

\begin{tabular}{l|rrrrrrrrr|r}
\hline Sample & $\mathrm{SiO}_{2}$ & $\mathrm{TiO}_{2}$ & $\mathrm{Al}_{2} \mathrm{O}_{3}$ & $\mathrm{Fe}_{2} \mathrm{O}_{3}$ & $\mathrm{CaO}$ & $\mathrm{Hg} 0$ & $\mathrm{Na}_{2} \mathrm{O}$ & $\mathrm{K}_{2} \mathrm{O}$ & Ig. loss & Total \\
\hline UG-L & 75.37 & 0.02 & 16.75 & 0.30 & 0.01 & 0.13 & 1.08 & 2.65 & 3.06 & 99.36 \\
UG-S & 75.51 & 0.02 & 16.86 & 0.29 & tr. & 0.13 & 0.98 & 2.53 & 3.16 & 99.54 \\
\hline UK-L & 77.08 & 0.04 & 16.96 & 0.33 & 0.01 & 0.14 & 0.49 & 2.18 & 3.49 & 100.73 \\
UK-S & 77.08 & 0.04 & 16.40 & 0.33 & 0.01 & 0.14 & 0.50 & 2.18 & 3.39 & 100.08 \\
\hline KS-L & 75.29 & 0.02 & 17.25 & 0.29 & 0.05 & 0.11 & 0.42 & 2.80 & 3.71 & 99.95 \\
KS-S & 75.29 & 0.02 & 17.39 & 0.27 & 0.03 & 0.12 & 0.40 & 2.81 & 3.82 & 100.14 \\
\hline
\end{tabular}

と特等石と同等の値となった。また, 有害と思われる $\mathrm{CaO}$ 含有量 は，0.05\%以下となった。

5）処理前後の粒度は大きく変化し, 処理物は細粒化した。しか し, 平均粒径 $0.12 \sim 4.78 \mathrm{~mm}$ に細粒化した本実験試料の水熱処理 後の洗浄工程に要する時間は, $3 \mu \mathrm{m}$ 以下の粒子が約 $60 \%$ 含ま れている陶土を精製する場合に比べ，大幅に短縮できると思われ る。

6）水熱処理原料の粒度の違いによる水熱処理後の鉱物組成, 而 火度, 白色度および化学組成の差は, ほとんよ゙認められなかった。

謝辞陶石試料の採取ならびに粗砕は天草陶石鉱業協同組合に お願いした。心より謝意を表する。

\section{引用文献}

1）林 文男・永田正典：セラミックス, Vol. 14, p. 333-338, (1979)

2) Gruner, J. W. : Econ. Geol., Vol. 39, p. 578-589, (1944)

3) Folk, R. W. : Am. Jour. Sci., Vol. 245, p. 388-394, (1947)

4）中川善兵衛：東京工業大学博士論文, p. 33-69, (1973)

5）木村邦夫・立山 博：日本セラミックス協会学術論文誌, Vol. 97, p. 439446, (1989)

6）富整幸雄：地質月報, Vol. 25, p. 491-508, (1974)

7）木村邦夫・石橋 修・陣内和彦：資源之素材，Vol. 109, p. 133-138, (1993)

8）木村邦夫 - 立山 博 - 石橋 修 - 陣内和彦 : 窯業協会誌, Vol. 94, p. 689693, (1986)

9）たとえば，窯業協会編集委員会編：窝業計測，p. 232 234, (1962), 窯業協 会 (東京)

10）素木洋一： セラミックス手帳, p. 326-327, (1972), 技報堂（東京）

11）木村邦夫・石橋 修・陣内和彦 : 資源・素材学会九州支部平成 4 年度春季例 会講演要旨集, p. $38-40,(1992)$ 